\title{
Evaluation of Antidepressant-like Effect of Olax Subscorpioidea Oliv. (Olacaceae) Extract in Mice
}

Authors

Affiliation

\author{
O. A. Adeoluwa, A. O. Aderibigbe , A. G. Bakre
}

Department of Pharmacology and Therapeutics, College of Medicine, University of Ibadan, Ibadan, Oyo State, Nigeria

\author{
Key words \\ - antidepressant \\ - mental illness \\ - immobility \\ - Olax subscorpioidea \\ - yohimbine
}

received 06.03.2014 accepted 16.05.2014

\section{Bibliography}

DOI http://dx.doi.org/

10.1055/s-0034-1382010

Published online:

July 3, 2014

Drug Res 2015;

65: 306-311

(c) Georg Thieme Verlag KG

Stuttgart · New York

ISSN 2194-9379

\section{Correspondence}

\section{O. A. Adeoluwa}

Department of Pharmacology

and Therapeutics

College of Medicine

University of Ibadan

Ojoo-Sango Road

Ibadan

Oyo State

Nigeria

Tel.: + 234/803/6925 173

adeoluwaolusegun@yahoo.com

\section{Abstract \\ $\nabla$}

Olax subscorpioidea is a shrub or tree found in Nigeria, and other parts of Africa. It is indicated in the management of inflammatory disorder, mental illness, convulsion, pain, and cancer.

Based on the folkloric use in the management of mental illness, antidepressant activity of Olax subscorpioidea $(6.25-50 \mathrm{mg} / \mathrm{kg}$, i.p.) was investigated using forced swimming, tail suspension, yohimbine induced lethality and reserpine induced depression tests.

The results showed that, Olax subscorpioidea produced significant dose dependent reduction in

\section{Introduction}

$\nabla$

Depression is an affective disorder characterized by change in mood, loss of interest or pleasure, feelings of guilt or low self-worth, disturbed sleep or appetite, low energy, psychomotor retardation and melancholia. It is a major health condition with life time prevalence in the range of 10-15\% [1]. World Health Organization [2] and Richelson et al., [3] estimated that $5.8 \%$ of men and $9.5 \%$ of women undergoing a depressive episode in their life time mostly end up committing suicide. Its negative social impact and impairing effect on daily activities and wellbeing has led to incapability and loss of productivity [4]. Most current therapeutic interventions employed in the management of depressive disorder are marred by their bizarre and undesirable side effects which tend to limit their clinical usefulness. Another drawback is that available treatments remain sub-optimal, with a delay of 3-6 weeks before their clinical effects can be achieved and lack of efficacy is also observed in many cases $[5,6]$.

In the light of the fact that plants present a large untapped source of structurally novel com- immobility time in forced swimming [F (5, $24)=17.22, \mathrm{p}<0.0001]$ and tail suspension $[\mathrm{F}(5$, $24)=14.94, \quad p<0.0001]$ tests without causing changes in locomotor activity in open field test. It was also found that Olax subscorpioidea significantly reduced diarrhea in reserpine model of depression $[F(5,24)=10, p<0.0001]$. None of the doses potentiated yohimbine induced lethality in mice. In conclusion Olax subscorpioidea possessed antidepressant action, thus justifying its use in the management of mental illness. pounds that might serve as lead for the development of novel drugs, the exploration of traditional source of medicine for more promising antidepressant drugs is justified. Studies have shown that herbs have been used as alternative therapy for depression [7]. Olax subscorpioidea (OS) locally called 'ifon' is a shrub or tree that is widely distributed in Nigeria and some parts of Africa. In Congo Republic folk medicine, stem with leaves of Olax subscorpioidea decoction, and steam bath have been used to treat rheumatism and articular pains [8]. Ethno-botanical survey showed that OS has been indicated in the management of asthma in South West Nigeria and as recipe for the management of cancer $[9,10]$. Its use in combination with another plant in the treatment of anxiety and mental illness disorders has been reported. [11]. Studies have shown that stem of OS contains alkaloids, steroids, and flavonoids together with other active ingredients in the ethanoic extract with the exception of saponins which is present in the aqueous extract alone and demonstrates antimicrobial activity [12]. Based on the ethnomedicinal use in mental illness and some other CNS disorders and lack of scientific report supporting its use in these conditions, the study 
is therefore, designed to evaluate antidepressant activity of Ethanol Extract of Olax subscorpioidea Leaves (EEOSL) in animal models.

\section{Materials and Methods \\ V \\ Plant materials}

The leaves of Olax subscorpioidea were collected in February 2012 at the Gambari Forest Reserve, Ibadan, the Oyo state capital, Nigeria. The taxonomical identification and authentication of the plant was done at the herbarium section of the Forestry Research Institute of Nigeria (FRIN), Ibadan, Nigeria. A voucher specimen with identification number 109924 was deposited and compared with the reference specimen.

\section{Preparation of plant material and drugs}

Air-dried leaves (150 g) were pulverized and soaked in 50\% ethanol $(1.5 \mathrm{~L})$ for $48 \mathrm{~h}$. The filtrate was concentrated with a rotary evaporator to give a semisolid residue and evaporated to dryness to form solid residue $(8.7 \mathrm{~g})$. It was kept in the desiccator for further use. The dried extract was then subsequently reconstituted in distilled water at appropriate concentrations for the various experiments. All drugs and the extract were dissolved in distilled water and administered by intraperitoneal (i. p.) route.

\section{Laboratory animal}

Male Swiss Albino mice (20-25g) used in this study were obtained from the Laboratory Animal Centre of the College of Medicine, University of Ibadan, Nigeria. The animals were kept in well-ventilated and hygienic compartments, maintained under standard environmental conditions and fed with standard rodent pellet (Livestock Feed PLC, Lagos, Nigeria) and water ad libitum. The experimental procedures adopted in this study were in accordance with the United States National Institutes of Health Guidelines for Care and Use of Laboratory Animals in Biomedical Research (NIH, 1985).

\section{Drugs and chemicals}

Yohimbine (Sigma-Aldrich (St.Louis, MO, USA), reserpine (Pfizer Inc., New York, NY, USA)., imipramine (Shanghai Zhongxi Pharmaceutical Co., Ltd. Shanghai, China).

\section{Acute toxicity test}

The method described by Lorke [13] was used to determine the $\mathrm{LD}_{50}$, which is the index of acute toxicity. Swiss Albino mice (20$25 \mathrm{~g}$ ) of either sex were used. This method involved an initial dose finding procedure, in which the animals were divided into 3 groups of 3 animals. Doses of 10,100 and $1000 \mathrm{mg} / \mathrm{kg}$ were administered intraperitonealy (i.p.). One dose for each group. The treated animals were monitored for $24 \mathrm{~h}$ mortality and general behavior. From the results of the above step, 4 different doses of $(500,800,2000$ and $3000 \mathrm{mg} / \mathrm{kg}$ ) were chosen and administered i.p. respectively to 4 groups of one mouse per group. The treated animals were monitored for $24 \mathrm{~h}$. The $\mathrm{LD}_{50}$ was then calculated as the geometric mean of the lowest dose showing death and the highest dose showing no death.

\section{Antidepressant activity}

Forced swimming test (FST)

Male mice (20-24g) were used in the forced swimming test [14]. Mice were assigned to 6 different groups ( $n=5$ for each group).
Group (1) received distilled water $(10 \mathrm{~mL} / \mathrm{kg})$, group (2-5) received OS $(6.2512 .5,25,50 \mathrm{mg} / \mathrm{kg})$ respectively while group (6) received Imipramine $(25 \mathrm{mg} / \mathrm{kg}) .30 \mathrm{~min}$ later, mice were dropped one at a time into a Plexiglas cylinder $(25 \mathrm{~cm}$ height, diameter $10 \mathrm{~cm}$ containing water to a height of $10 \mathrm{~cm}$ at $23-25^{\circ} \mathrm{C}$ ) and observed for $6 \mathrm{~min}$. After the first $2 \mathrm{~min}$ of the initial vigorous struggling, the animals were immobile. A mouse was judged immobile if it floated in the water in an upright position and made only slight movements to prevent sinking. The total duration of immobility was recorded during the last $4 \mathrm{~min}$ of the 6 min test.

\section{Tail suspension test}

The total duration of immobility following tail suspension was measured according to the method described for evaluating potential antidepressants [15]. Mice were assigned to 6 different groups ( $\mathrm{n}=5$ for each group). Group (1) received distilled water $(10 \mathrm{~mL} / \mathrm{kg})$, group $(2-5)$ received OS $(6.2512 .5,25,50 \mathrm{mg} / \mathrm{kg})$ respectively while group (6) received Imipramine $(25 \mathrm{mg} / \mathrm{kg}$ ). $30 \mathrm{~min}$ later mice were suspended on the edge of a table, $50 \mathrm{~cm}$ above the floor with the help of an adhesive tape placed approximately $1 \mathrm{~cm}$ from the tip of the tail. Immobility time was recorded during $6 \mathrm{~min}$ period in different groups. The animal was considered to be immobile when it did not show any movement of the body and hanged passively.

\section{Open field Test (OFT)}

In order to rule out any unspecific locomotor effect of olax subscorpioidea on antidepressant-like effect of these compounds, mice were administered with the same regimen as in FST or TST. Their locomotor activities (crossing activity) were evaluated in the open field paradigm. Before each test, animals were kept in the test room at least $1 \mathrm{~h}$ before open-field test (OFT) for habituation. The ambulatory behaviour was assessed in open-field described by Rodrigues et al. [16]. The main apparatus consisted of square arena $(50 \mathrm{~cm} \times 50 \mathrm{~cm} \times 40 \mathrm{~cm})$ high with grey surface covering every wall. The floor of the arena was divided equally into 25 squares $(10 \mathrm{~cm} \times 10 \mathrm{~cm})$ marked by black lines. All animals were used only once in this test. These animals were different from those used in the FST and TST. Group (1) received distilled water $(10 \mathrm{~mL} / \mathrm{kg})$, group (2-5) received OS (6.25 12.5, $25,50 \mathrm{mg} / \mathrm{kg}$ ) respectively while group (6) received Imipramine ( $25 \mathrm{mg} / \mathrm{kg}$ ). $30 \mathrm{~min}$ after, each mouse was placed individually at the center of the arena and allowed to explore freely. The number of squares crossed with all paws (crossing) were observed and counted in $5 \mathrm{~min}$. The square arena was cleaned with a solution of $70 \%$ alcohol between tests and dried after occupancy by each mouse in order to hide animal clues and to prevent each mouse from being influenced by the odors present in the urine and feces of the previous mouse.

\section{Yohimbine induced lethality test}

To reveal whether noradrenergic system is involved in the antidepressant-like effect of the extract, yohimbine induced lethality test was performed [17]. Mice were assigned to 6 different groups ( $n=5$ for each group). Group (1) received distilled water $(10 \mathrm{~mL} / \mathrm{kg})$, group $(2-5)$ received OS $(6.2512 .5,25,50 \mathrm{mg} / \mathrm{kg})$ respectively while group (6) received Imipramine $(25 \mathrm{mg} / \mathrm{kg})$ $30 \mathrm{~min}$ prior to yohimbine administration $(35 \mathrm{mg} / \mathrm{kg}$, intraperitoneal injection). The number of dead mice was calculated during a $24 \mathrm{~h}$ period after injection of yohimbine. 
Reserpine induced depression

6 groups of animal (Group 1-6) were reserpinised by administration of reserpine $(2.5 \mathrm{mg} / \mathrm{kg}$, i. p.) $1 \mathrm{~h}$ after the respective drug administration. Group (1) received distilled water $(10 \mathrm{~mL} / \mathrm{kg})$, group (2-5) received OS $(6.2512 .5,25,50 \mathrm{mg} / \mathrm{kg})$ respectively while group (6) received Imipramine $(25 \mathrm{mg} / \mathrm{kg})$. The acute effects of Olax subscorpioidea and Imipramine on reserpine induced diarrhea were observed. Mice were observed for the presence of diarrhea at 1, 2, $3 \& 4 \mathrm{~h}$ after reserpine injection.

\section{Statistical analysis}

All data are presented as mean \pm SEM. The results were analyzed by One way analysis of variance (ANOVA) and post hoc tests (Student's-Newman-Keuls) were carried out to determine the source of significant main effect using GraphPad InStat ${ }^{\circledR}$ Biostatistics software. The level of significance for all tests was set at $\mathrm{p}<0.05$.

\section{Results}

$\nabla$

\section{Acute toxicity test}

The $\mathrm{LD}_{50}$ of Olax subscorpioidea crude extract in mice was found to be $300 \mathrm{mg} / \mathrm{kg}$ i. p. body weight.

\section{Effect of olax subscorpioidea on immobility time of forced swimming test (FST)}

OS at $6.25 \mathrm{mg} / \mathrm{kg}$ and $12.5 \mathrm{mg} / \mathrm{kg}$ significantly reduced $(\mathrm{P}<0.05)$ immobility time of mice in FST as compared to the control (vehicle) while doses at $25 \mathrm{mg} / \mathrm{kg}$ and $50 \mathrm{mg} / \mathrm{kg}$ did not reduce immobility time in mice. Clinically effective antidepressant imipramine at $25 \mathrm{mg} / \mathrm{kg}$ produced a marked significant reduction $(\mathrm{P}<0.05)$ in the duration of immobility as compared with control (० Fig. 1).

\section{Effect of olax subscorpioidea on immobility time of tail} suspension test (TST)

OS at $6.25 \mathrm{mg} / \mathrm{kg}$ and $12.5 \mathrm{mg} / \mathrm{kg}$ significantly reduced $(\mathrm{P}<0.05)$ immobility time of mice in TST as compared to the control while

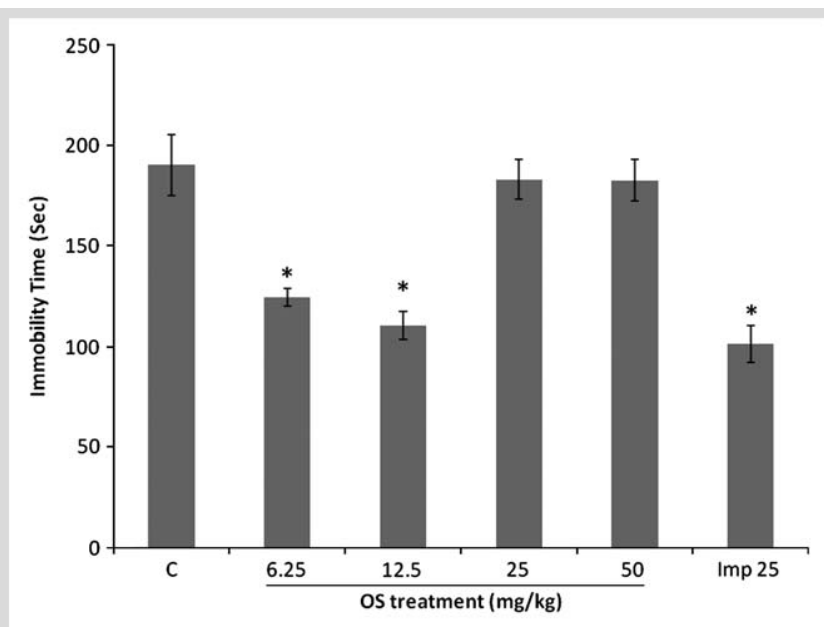

Fig. 1 Effect of OS on immobility time of Forced Swimming Test (FST). The results are expressed as Mean $\pm \operatorname{SEM}(n=5)$. One way ANOVA revealed that there is significant $[F(5,24)=17.22, p<0.0001]$ difference between various treatment groups. ${ }^{*}$ indicates significant difference from the control $\mathrm{P}<0.05$. Imp = imipramine $(25 \mathrm{mg} / \mathrm{kg}) ; \mathrm{C}=$ control; OS = olax susbscorpioidea doses at $25 \mathrm{mg} / \mathrm{kg}$ and $50 \mathrm{mg} / \mathrm{kg}$ did not reduce immobility time in mice. The clinically effective antidepressant imipramine at $25 \mathrm{mg} / \mathrm{kg}$ produced a marked significant reduction $(\mathrm{P}<0.05)$ in the duration of immobility as compared with control ( $\bullet$ Fig. 2 ).

\section{Effect of OS on locomotor activity of OFT}

Treatment with OS at $6.25 \mathrm{mg} / \mathrm{kg}$ and $12.5 \mathrm{mg} / \mathrm{kg}$ which significantly reduced duration of immobility in FST and TST produced no significant difference in number of crossing activity of mice in OFT. Antidepressant Imipramine at $25 \mathrm{mg} / \mathrm{kg}$ which reduced duration of immobility of mice in FST and TST produced no significant difference in number of crossing activity as compared to control ( $\odot$ Fig. 3).

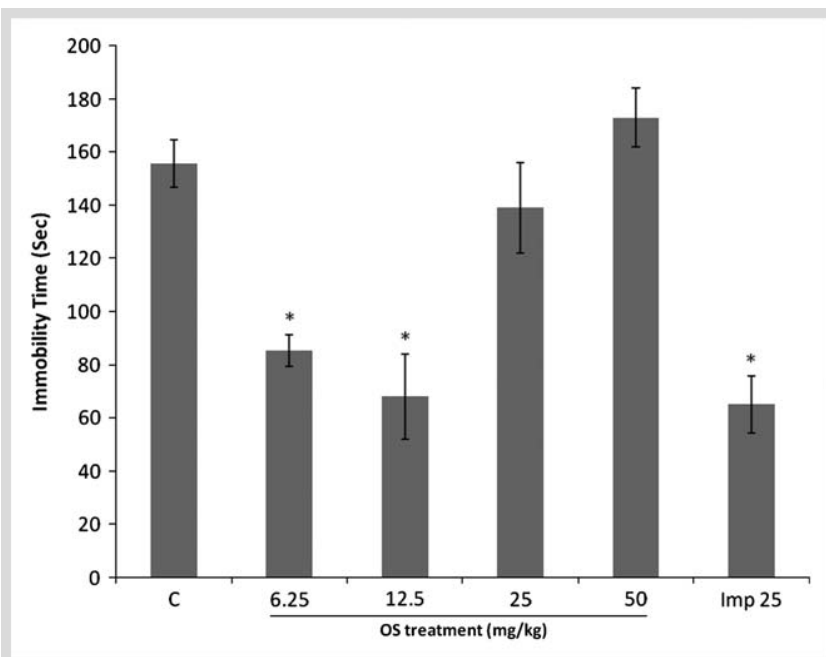

Fig. 2 Effect of OS on immobility time of Tail Suspension Test (TST). The results are expressed as mean \pm SEM $(n=5)$. One way ANOVA revealed that there is significant $[F(5,24)=14.94, p<0.0001]$ difference between various treatment groups. ${ }^{*}$ indicates significant difference from the control $\mathrm{P}<0.05$. Imp = imipramine ( $25 \mathrm{mg} / \mathrm{kg}) ; \mathrm{C}=$ control; OS= olax susbscorpioidea

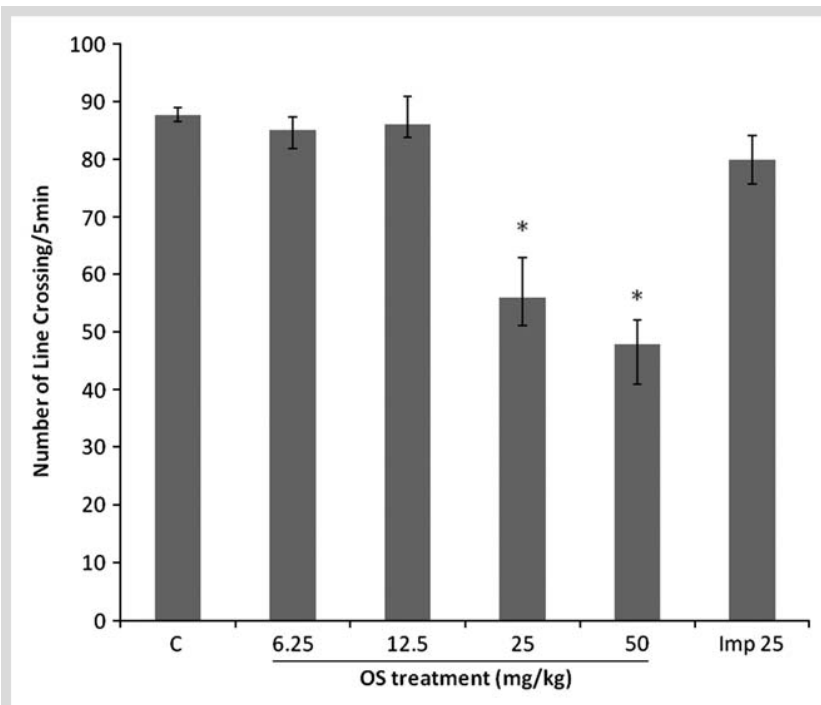

Fig. 3 Effect of OS on the locomotor activity of mice in OFT. The results are expressed as mean \pm SEM $(n=5)$. One way ANOVA revealed that there is significant $[F(5,24)=35.98, p<0.0001]$ difference between various treatment groups. ${ }^{*}$ Indicates significant difference from the control $\mathrm{P}<0.05$. Imp = imipramine $(25 \mathrm{mg} / \mathrm{kg}) ; \mathrm{C}=$ control; OS = olax susbscorpioidea. 


\section{Effect of olax subscorpioidea on yohimbine induced lethality test}

Comparing with control OS (6.25-50 mg/kg) did not significantly potentiate yohimbine toxicity in mice. Antidepressant imipramine at $25 \mathrm{mg} / \mathrm{kg}$ produced a marked significant increase in the number of death $(\mathrm{P}<0.05)$ as compared with control (० Table 1).

\section{Effect of crude extract of olax subscorpioidea in reserpine induced depression}

In reserpine induced depression test, OS $(6.25,12.5,25,50 \mathrm{mg} /$ $\mathrm{kg})$ produced significant $(\mathrm{p}<0.05)$ decrease in the mean feacal droppings in all the groups compared to control. Anti-diaorrhea effect of Olax subscorpioidea was comparable to that of imipramine ( $\bullet$ Table 2 ).

\section{Discussion}

Behavioural studies have been shown to play an important part in the evaluation and development of antidepressant drugs [18]. Forced swimming test (FST) and tail suspension test (TST) are 2 important behavioural models widely and routinely used for screening new antidepressant compounds [19]. According to Porsolt [20] and Steru et al., [21] existence of significant correlation between clinical potency and potency of antidepressants has been established. The immobility displayed by animals subjected to an unavoidable and inescapable stress that characterizes these models has been hypothesized to reflect behavioural despair which in turn may reflect depressive disorder in humans. This immobile position is reduced by variety of therapeutically active antidepressants e.g. tricyclics, monoamine oxidaseinhibitors, and newer antidepressants [22,23].

Forced swimming test is based on the assumption that animals forced to swim in a restricted space will ultimately cease to apparent attempts to escape and become immobile making only small movements necessary to keep their heads above the sur-

Table 1 Effect of Olax subscorpioidea on Yohimbine-induced lethality Test.

\begin{tabular}{|lcll|} 
Group & Dose $\mathbf{( m g / k g )}$ & No of death & $\%$ mortality \\
\hline Distilled water & $10 \mathrm{~mL} / \mathrm{kg}$ & $2 / 10$ & 20 \\
\hline Olax subscorpioidea & 6.25 & $2 / 10$ & 20 \\
\hline & 12.5 & $0 / 10$ & 0 \\
& 25 & $0 / 10$ & 0 \\
\hline & 50 & $2 / 10$ & 20 \\
\hline Imipramine & 25 & $7 / 10$ & $70^{*}$
\end{tabular}

The results are expressed as mean \pm SEM $(n=5)$. One way ANOVA revealed that there is significant $[F(5,24)=21.73, p<0.0001]$ difference between imipramine and the control

*indicates significant difference from the control $\mathrm{P}<0.05$ face of water [24]. In this present study however, OS (6.25 and $12.5 \mathrm{mg} / \mathrm{kg}$ ) produced a statistically significant reduction in immobility time in forced swimming test, while OS (25 and $50 \mathrm{mg} / \mathrm{kg}$ ) produced no effect on immobility time. Positive control antidepressant drug imipramine produced significant reduction in immobility time. Therefore the ability of OS to reduce immobility time in animals subjected to this stressful situation indicates its antidepressant like activity.

Similar results were obtained in TST with OS (6.25 and $12.5 \mathrm{mg} /$ $\mathrm{kg}$ ) and imipramine $(25 \mathrm{mg} / \mathrm{kg})$ producing significant reduction in immobility time while OS ( 25 and $50 \mathrm{mg} / \mathrm{kg}$ ) did not affect immobility in these animals. The test having got an advantage of being able to detect broad spectrum of antidepressants irrespective of their mechanism of action, is however based on the observation that rodents mostly mice after initial escape behaviour, develop an immobile position when subjected to an inescapable stressful situation [25]. Animals are considered as immobile when they hang passively and completely motionless. The development of immobile posture by the animals which disengages them from active form of coping with stressful stimuli [26] represents behavioural despair which in turn may reflect depressive disorders in humans. Clinically effective antidepressants decrease immobility time in TST. The ability of the extract (OS) to reduce immobility time suggests that it may possess antidepressant activity.

While interpreting antidepressant-like effect of any test substance based on swimming performance and exploratory behaviour of rodents in either FST or TST, it is noteworthy that false positive results can be obtained for agents that stimulate locomotor activity [27]. Therefore the influence of the test substance in baseline locomotion in animal is of prime concern [28]. Agents like amphetamine, convulsants and anticholinergic which enhance locomotor activity or cause hyperkinesias in open field test (OFT) produce false positive results in FST and TST $[27,29,30]$. Hence the need of OFT as a paradigm to eliminate the bias that anti-immobility effect could be associated with hyperkinesia [31]. As psycho-stimulant will always give false positive result in FST and TST, one way to discern or discriminate between antidepressants and psycho-stimulants is that antidepressants would not cause general increase in motor activity [32]. Potential antidepressant activities of selective serotonin1 A agonists based on anti-immobility activity in the forced swimming test in rats without effect on open-field activity have been suggested [33]. The observation that OS $(6.25$ and $12.5 \mathrm{mg} / \mathrm{kg})$ did not increase the number of line crossed in open field eliminates exertion of psycho-stimulant-like action and confirms the assumption that antidepressant-like effect of the extract in TST and FST is specific [34]. Conversely, OS (25 and $50 \mathrm{mg} / \mathrm{kg}$ ) statistically produced a significant reduction in the number of line crossed indicating gross sedation at these doses which masks its

\begin{tabular}{|c|c|c|c|c|c|c|}
\hline Group & Dose $\mathrm{mg} / \mathrm{kg}$ & $60 \mathrm{~min}$ & $120 \mathrm{~min}$ & $180 \mathrm{~min}$ & $240 \mathrm{~min}$ & \multirow{7}{*}{$\begin{array}{l}\text { Table } 2 \text { Effect of crude extract } \\
\text { of Olax subscorpioidea in Reserpine } \\
\text { Induced Diarrhoea. }\end{array}$} \\
\hline Control & $10 \mathrm{~mL} / \mathrm{kg}$ & $4.80 \pm 0.80$ & $7.60 \pm 0.92$ & $8.20 \pm 0.86$ & $6.51 \pm 0.73$ & \\
\hline \multirow[t]{4}{*}{ Olax subscorpioidea } & 6.25 & $1.60 \pm 0.50^{*}$ & $1.80 \pm 0.66^{*}$ & $2.40 \pm 0.92^{*}$ & $2.63 \pm 1.12^{*}$ & \\
\hline & 12.5 & $1.20 \pm 0.58^{*}$ & $1.20 \pm 0.58^{*}$ & $1.20 \pm 0.58^{*}$ & $2.01 \pm 0.35^{*}$ & \\
\hline & 25 & $0.40 \pm 0.24^{*}$ & $0.60 \pm 0.40^{*}$ & $1.20 \pm 0.37^{*}$ & $1.78 \pm 1.09^{*}$ & \\
\hline & 50 & $1.00 \pm 0.44^{*}$ & $1.20 \pm 0.37^{*}$ & $2.80 \pm 0.58^{*}$ & $1.58 \pm 0.55^{*}$ & \\
\hline Imipramine & 25 & $0.71 \pm 0.24^{*}$ & $0.82 \pm 0.28^{*}$ & $1.56 \pm 0.34^{*}$ & $0.92 \pm 0.35^{*}$ & \\
\hline
\end{tabular}


antidepressant effect. This probably explains why the extract at higher doses could not exhibit anti-immobility effect seen at lower doses.

Yohimbine induced lethality test is another animal model used to further screen antidepressant potential of olax subscorpioidea. This model has been developed not only to detect potential antidepressant properties of new substances, but also to identify neurotransmitter systems that may be involved in the mechanism of actions of antidepressant drugs [35]. Yohimbine, an alpha 2 adrenergic antagonist, causes increased sympathetic discharge both in the peripheral and central nervous system. The antagonism of alpha 2 receptors also causes an increase in the level of serotonin [36]. Antidepressant drugs by enabling more amines to reach the receptors potentiate yohimbine induced lethality. This occurs either by their reuptake inhibition or reduced inactivation by monoamine oxidase inhibitors. Yohimbine induced lethality test reveals an adrenergic component of pharmacological activity of antidepressants and is sensitive to detect MAO inhibitors, tricyclic antidepressants, noradrenaline (NA), and selective serotonin reuptake inhibitors [37]. The present study showed that OS did not potentiate yohimbine induced lethality at all doses thus precluding involvement of the central adrenergic mechanism in its antidepressant action.

Studies have shown that reserpine can deplete amine stores and irreversibly inhibit the vesicular uptake of monoamines. This reduced level of monoamines in the brain has been implicated to be an underlining factor in the pathophysiology of depression. In this paradigm, physiological effects such as diarrhoea, ptosis and hypothermia are observed and these have been associated with the effect of reserpine as signs of depression [38]. These syndromes have been inhibited or reversed by major classes of antidepressant drugs. In this study, like imipramine significant reversal of diarrhoea by OS at all 4 dose levels used was noticed and thus indicating its antidepressant property.

In conclusion, it is obvious that administration of OS produced antidepressant-like effect in FST and TST, which is not due to the effect of psycho-stimulant or hyperkinesia. However, giving the fact that Forced swimming, Tail suspension, yohimbine induced lethality and reserpine induced depression tests are not the only models of depression by which the results obtained can be considered, interpreted and validated due to individual differences among experimental animals and clinical studies in human, there is therefore the need to advance the course of the study by evaluating the effect of the extract (OS) in other animal's behavioural model including relevant antidepressant doses of OS on its safety and efficacy level.

\section{Acknowledgement}

$\nabla$

We thank Dr. S Umukoro and the technical staff of Department of pharmacology and Therapeutic, University of Ibadan for the support.

\section{Conflict of Interest}

$\nabla$

The authors stated that there is no conflict of interest regarding the publication of this article.

\section{References}

1 Lépine JP, Briley M. The increasing burden of depression Neuropsychiatric Disease and Treatment 2011; 3-1

2 WHO. Mental and Neurological Disorders. Fact sheet No. 25. World Health Organization, 1998

3 Richelson E. Mayo Clin Proc 2001; 76: 516-527

4 Ebmeier KP, Donaghey C, Steele JC. Recent developments and current controversies in depression. Lancet 2006; 367: 153-167

5 Nestler EJ, Barrot M, DiLeone RJ et al. Neurobiology of depression. Neuron 2002; 34: 13-25

6 Dhingra S, Parle M. Herbal remedies and nutritional supplements in the treatment of depression: a review. Bulletin of Clinical Psychopharmacology 2012; 22: 286-292

7 Kessler RC, Chiu WT, Demler O et al. Prevalence, severity, and comorbidity of 12-month DSM-IV disorders in the National Comorbidity Survey. Replication Arch Gen Psychiatry 2005; 62: 617-627

8 Bouquet A. Féticheurs et médecines traditionnelles du Congo (Brazzaville) Mém. O R S T O M 1969; 36: 282 http://www.docstoc.com/ docs/41737230/Ficheurs-et-mecines-traditionn

9 Sonibare MA, Gbile ZO. Ethnobotanical survey of anti-asthmatic plants in south western Nigeria Afr. J Trad CAM 2008; 5: 340-345

10 Mike OS, Amusa NA, Raji-Esan SO et al. Ethnobotanical Survey of AntiCancer Plants in Ogun State. Nigeria Annals of Biological Research 2010; 1: 261-273

11 Ibrahim JA, Muazzam I, Jegede IA et al. Ethno-medicinal plants and methods used by Gwandara tribe of Sabo Wuse in Niger state. Nigeria, to treat mental illness African Journal of Traditional, Complementary and Alternative Medicines 2007; 4: 211-218

12 Ayandele AA, Adebiyi AO. The phytochemical analysis and antimicrobial screening of extracts of olax subscorpioidea. African Journal of Biotechnology 2007; 6: 868-870

13 Lorke D. A new approach to practical acute toxicity testing. Arch Technol 1983; 54: 275-282

14 Porsolt RD, Bertin A, Jalfre M. Behavioral despair in mice: a primary screening test for antidepressants. Arch Int Pharmacodyn Ther 1977; 229: $326-327$

15 Rodrigues ALS, Silva GL, Matteussi AS et al. Involvement of monoaminergic system in the antidepressant-like effect of the hydroalcoholic extract of Siphocampylus verticillatus. Life Sci 2002; 70: 1347-1358

16 Rodrigues AL, Rocha JB, Mello CF et al. Effect of perinatal lead exposure on rat behavior in open-field and two-way avoidance tasks. Pharmacol Toxicol 1996; 79: 150-156

17 Voger HG, Voger WH. Drug Discovery and Evaluation-Pharmacological Assays; antidepressant activity. Springer-Verlag, Berlin heidelberg: 1997; 411

$18 X u Q$ Yi LT, Pan Y et al. Antidepressant-like effects of mixture of honokiol and magnolol from the barks of Magnolia officinalis in stressed rodents. Prog Neuropsychopharmacol Biol Psychiatry 2008; 32: 715-725

19 Cryan JF, Mombereau C, Vassout A. The tail suspension test as a model to assessing antidepressant activity: review of pharmacological and genetic studies in mice. Neurosci Biobehav Rev 2005; 29: 571

20 Porsolt RD. Behavioural Despair, in antidepressants: Neurochemical, behavioural and clinical Perspectives. Ed by Enna SJ, Malick JB, Richelson E. Raven Press, New York: 1981; 121-139

21 Steru L, Chermat R, Thierry B. The automated tail suspension test: a computerized device which differentiates psychotropic drugs Prog Neuropsychopharmacol. Biol Psychiatry 1987; 11: 659-671

22 Cryan JF, Lucki I. Antidepressant-like behavioral effects mediated by 5- hydroxytry-ptamine(2C) receptors. Journal of Pharmacology and Experimental Therapeutics 2000; 295: 1120-1126

23 Cryan JF, Markou A, Lucki I. Assessing antidepressant activity in rodents: recent developments and future need. Trends in Pharmacological Sciences 2002; 23: 238-245

24 Porsolt RD, Anton G, Blavet $N$ et al. Behavioral despair in rats A new animal model sensitive to antidepressive treatments. Eur J Pharmacol 1978; 47: 379-391

25 Varty GB, Cohen-Williams ME, Hunter JC. The antidepressant- like effects of neurokinin NK1 receptor antagonists in a gerbil tail suspension test. Behav Pharmacol 2003; 14: 87-95

26 Lucki I. A prescription to resist proscriptions for murine models of depression. Psychopharmacology 2001; 153: 395-398

27 Bourin M, Fiocco AJ, Clenet F. How valuable are animal models in defining antidepressant activity? Hum Psychopharmacol 2001; 16: 9-21

28 Boissier JR, Simon P. Action of caffeine on the spontaneous motility of the mouse. Arch Int Pharmacodyn Ther 1965; 158: 212-221 
29 Butterweck $V$, Christoffel $V$, Nahrsted A et al. Step by step removal of hyperforin and hypericin: activity profile of different Hypericum preparations in behavioral models. Life Sci 2003; 73: 627-639

30 Takahashi E, Katayama M, Nimii K et al. Additive sub threshold dose effects of cannabinoid CB1 receptor antagonist and selective serotonin re uptake inhibitor in antidepressant behavioral tests. Euro J Pharmacol 2008; 589: 149-156

31 Kwon S, Lee B, Kim M et al. Antidepressant-like effect of the methanolic extract from Bupleurum falcatum in the tail suspension test Prog Neuropsychopharmacol. Biol Psychiatry 2009; 34: 265-270

32 Borsini F, Meli $A$. Is the forced swimming test a suitable model for revealing antidepressant activity? Psychopharmacology 1988; 94: $147-160$

33 Cervo L, Samanin R. Evidence that dopamine mechanisms in the nucleus accumbens are selectively involved in the effect of desipramine in the forced swimming test. Neuropharamcology 1987; 26: 1469
34 Sánchez-Mateo CC, Bonkanka CX, Prado B et al. Antidepressan properties of some Hypericum canariense $\mathrm{L}$ and Hypericum glandulosum Ait Extracts in the forced swimming test in mice. J Ethnopharmacol 2005; 97: 541-547

35 Leonard BE. Mechanism of action of antidepressants: relevance to understanding the psychobiology of depression? Clin Neuropharmacol 1986; 9: 67-69

36 Blier P, Montigny C. Current advances and trends in the treatment of depression. Trends Pharmacol Sc 1994; 15: 220-226

37 Malick JB. Potentiation of Yohimbine-induced lethality in mice: predictor of antidepressant potential. Drug Dev Res 1983; 3: 357-363

38 Bourin $M$, Poncelet $M$, Chermat $R$ et al. The value of the reserpine test in psychopharmacology. Arzneimittel-Forschung/Drug Research 1983; 33: 1173-1176 